69 Fr. Pat. 2,007,925

70 U.K. Pat. 1 152 817, Fr. Pat. 1,567,440 and U.S. Pat. 3,476,808

71 U.S. Pat. $3,553,220$

72 U.S. Pat. 3,742,070

73 German Offett. 1909959

74 W.A. Bone and G.W. Andrew, Proc. Roy. Soc. (London), 1925, 109A, 459

75 D.Y. Cha and G. Parravano,J. Catal., 1970, 18, 200-211

76 J.D. Brandner and H.C. Urey, Y. Chem. Phys., 1945, 13, 351-362

77 S. Galvagnoand G. Partavano, Ber. Butzsenges, Pbys. Cbem., 1979,83,894-899

78 N.W. Cant and P.W. Frederickson, J. Cata. , 1975, 37, 531-539

79 D.J.C. Yates, Colloid Interface Sci., 1969, 29, 194-204; C.R. Guerra and J.H. Schulman, Surf. Sci, 1967, 7, 229-249; C.R. Guerra, Colloid Interface Sci. $1969,29,229-234$

80 A.M. Bradshaw and J. Pritchard, Proc. Roy. Soc. (London), 1970, A316, 169

81 M.L. Kottke, R.G. Greenlet and H.G. Tompkins, Surf. Sci., 1972, 32, 231

82 J. Schwank, G. Parravano.and H.L. Gruber, J. Catal., 1980, 61, 19-28

83 G.R. Hennig, J. Inorg. Nucl: Chem., 1962,24, 1129-1137

84 V.E. Ostrovskifiand N.N. Dobrovol'skii, in 'Proc, 4thInt. Congr. Catal.', Vol. 2, p. $9-19,1968$

85 W.R. Patterson and C. Kemball, J. Catal., 1963, 2, $465-478$

86 N.W. Cant and W.K. Hall, J. Phys. Chem., 1971, 75, 2914-2921

87 G. Manara and G. Parravano, J. Catal., 1971, 23, 379-387

88 G. Manara and G. Parravano, J. Catal., 1974, 32, 72

89 E.T. Blues, D. Bryce-Smith, I.W. Lawston and G.D. Wall,J. Chem. Soc. Chem. Commun., 1974, 513-514

E.T. Blues, D. Bryce-Smith and I.W. Lawston, Gold Bull., 1976,9, 88-90

90 J. Figar and W. Haidinger, Gold Bull., 1974, 7, 100-102

91 J. Figar and W. Haidinger, Chem. Phys, Lett., 1973, 19, 564-570

92 U.K. Pat.462 487, German Pat. 1192280

93 N.H.A. Van Ham, B.E. Nieuwenhuys and W.M.H. Sachtler J. Catal. , 1971, 20, 408-411

94 V.V. Shalya, F.A. Yampol'skaya, R.A. Svishchuk and Ya. B. Gorokhovatskii, Kinet. Katal., 1973, 14,993

95 G.K. Boreskovi M.G. Slin'ko andE.I. Volkova, Dokl. Akad. NawkSSSR, 1953,92, 109-110

96 C.G. Vayenas and H.M. Saltsburg, J. Catal. . 1979, 57, 296-314

97 J. Schwank, S. Galvagno and G. Parravano, J. Catal, 1980, 63, 415-424

98 W.M.H. Sachtler, G.J.H. Dorgelo and A.A. Holsher, Surf. Sci., 1966, 5, 221

99 T.S. Starostina, A.V. Khasin, G.K. BoreskovandL.M. Plyasova, Dokl. Akad. Nauk SSSR, 1970, 190, 394

100 E.R.S. Winter.J. Chem. Soc. (London), 1968, A 2889
101 A. Cros, J. Derrien and F. Salvan, Surf. Sci. , 1981, 110, 471-490

102 K. Gossnerand H. Bischof, Z, Pbys. Cbom. (Frankfutt), 1972, 78, 277-297, and $1972,79,78-82$

103 M. Dole, D.F.P. Rudd, G.R. Muchow and C. Comte, J. Chem. Phys., 1952, 20 961-968

104 Y.Ono, T. Matsumuta, N. KitajimaandS. Fukuzumi, J, Phys. Chem., 1977,81, 1307

105 K. Tamura, K. Tarama and E. Suito, Nipponz Kagaku Zasshi, 1959, 80, 10

106 S. Kishimoto and M. Nishioka, J. Pbys. Chem., 1972, 76, 1907-1908

107 S. Kishimoto, J. Phys. Cbem., 1973, 77, 1719

108 M.A. Bhakta and H.A. Taylor, J. Cbem, Pbys., 1966, 44, 1264-1270

109 V.D. Yagodovskii and D.N. Gruzdev, Kinet. Katal., 1969, 10, 833

110 M.A. Bhakta, Corr. Sci. , 1981, 50,490-491

111 W.M.H. Sachtler and I. Fahrenfort, in 'Proc. 2nd Int. Congr. Caral.', Vol. 1, Paris, 1960, (publ. 1961), pp. 838-848.

11.2 W.M.H. Sachtler and N.H. deBoer,J. Phys. Chem., 1960, 64, 1579-1580

113 J. Fahrenfort, L.L. van Rijen and W.M.H. Sachtler, in 'Proc. Symp. Mech. Heterogen. Catal., Amsterdam, 1959, pp. 23-48.

1.14 D.D. Eley and P. Luetic. Trans. Faraday Soc, 1957, 53, 1483-1487

115 G.M. Schwab and G. Holz, Z. Anorg. u. Allgem. Chem., 1944, 252, 205

116 G.M. SchwabandH. Knoezinger, Z. Phys. Chem. (Frankfutt), 1963,37,230-242

117 C.N. Hinshelwood and C.R. Prichard, Proc. Roy. Soc. (London), 1925, 108A, 211

118 D.D. Eley and C.F. Knights, Proc. Roy. Soc., 1966, A294, 1-19

119 V.M.Stepanov, V.D. Yagodovskiiand H. Agilar,Russ.J. Phys. Chem., 1975, 49 2275-2279

120 J.G. Hardy and M.W. Roberts, J. Chem. Soc. D. , 1971, (10), 494-495

121 C.N. Hinshelwood and C.R. Prichard, J. Chem. Soc., 1925, 127, 1551-1555

'122 A.G. Nasini, G. Saini, L. TrosarelliandE. Campi, in 'Proc. 2nd Int. Congr. Catal' Vol. 2, Paris, 1960 (publ. 1961), p. 1873

123 A.G. Nasin, G. Saini and L. Trosarelli, Pure Appl. Chem. , 1962, 4, 255-270

124 German Pat. 1277249 ,Jabanese Kokai 73-71387, German Offen. 2511364

125 Y. Anju, I Mochida, H. Yamamoto, A. Katoand T. Seiyama, Bull. Chem. Soc Jpn., 1972, 45, 2319

126 R.N. Haszeldine and F. Smith, J. Chem. Soc., 1950, 2689-2694

127 L. Balsenc, H. Berthou and C.K. Joergensen, Cbimia, 1975, 29, 64

128 S.A. Cochfan and H.H. Farrell, Surf. Sci, 1980, 95, 359

129 F.P. Netzer, E. Bertel and J.A.D. Matchew, Solid State Commun., 1980, 33, 519

130 E. Bertel and F.P. Netzer, Surf. Sci, , 1980, 97, 409

131 K. Kishi and S. Ikeda, J. Pbys. Chem., 1974, 78, 107

132 N.D. Spencer and R.M. Lambert, Suff, Sci., 1981, 107, 237

\title{
Goldsmithing in Ancient Times
}

\section{Jewellery of the Ancient World BYJACKOGDEN, Trefoil Books, London, 1983, 250 pages, 630}

To the metallurgist concerned with gold and its many alloys there is a fascination in the study of the skills and knowledge characteristic of ancient goldsmiths and jewellers, increasing with the greater interest being taken in it in recent years by archaeologists. The present study covers the period from the earliest Egyptian work to the end of the Roman era, a very long phase in which the technology gradually became more sophisticated.

The author, who combines the flair of the connoisseur with the techniques of both the archiaeologist and the metallurgist, gives a detailed account of the sources of gold, as well as of silver, copper and tin, in antiquity and then surveys the methods of work. ing the metals and alloys - 'those loveliest secrets and wondrous methods of the great art of goldsmithing' as Benvenuto Cellini wrote, his territory ranging from Persia to lreland. At the same time he considers the artifacts in the context of the craftsmen who made them and the cultures that produced these men and their work.

In the early periods in Egypt and elsewhere all types of naturally occurring gold alloys, often containing considerable proportions of silver (and then known of course as electrum) were used, but by about the year 2000 B.C. intentional additions of both silver and copper were made in many parts of the Near East and Europe. Goldsmithing techniques dealt with include not only the obvious methods of sheet metal work, cutting and piercing, engraving, wire and chain making and casting, but alsosoldering and the ingenious production, by the addition of silver and copper to the gold to yield both lower melting temperatures and appropriate colours, of suitable solders to ensure that the joints were unobtrusive in appearance.

A bout half of the work deals with gold, the remainder being concerned with gemstones. It concludes with a useful chapter on fakes and forgeries and the techniques employed in their production.

The book is extremely well illustrated with some two hundred black and white photographs and thirty six in colour, almost all of excellent examples of ancient jewellery. There is also an extensive bibliography but, by a regrettable economy on the part of the publisher, the index has been omitted. However, the book forms a major addition to our knowledge of gold metallurgy and fabrica. tion in antiquity, and a tribute to the highly skilled craftsmen of the past.
L.B.H. 